\title{
Older child adoption: A study of the affiliation process
}

\author{
Adoção da criança maior: um \\ estudo do processo filiativo
}

\author{
Carolina Lemos da SILVA ${ }^{1}$ \\ Silvia Pereira da Cruz BENETTI ${ }^{1}$
}

\begin{abstract}
This study's aim was to present a case study on the adoption of two older siblings and interpret how paternal filiation was constructed in this process. Data was collected through interviews held in 14 meetings over the course of six months. Data were also obtained from personal diaries completed by the participants. The material was analyzed based on the psychodynamic approach to identify specific aspects of parenthood and filiation, as well as utilizing the stages of the family living together. Listening to the family at times of greater ambivalence at different stages helped the adoption process and the children's filiation. The conclusion is that forming a family in adopting older children should not be associated with greater difficulties in filiation, as long as that appropriate support is provided to meet both the parents' and the children's needs concerning the process.
\end{abstract}

Keywords: Adoption (child); Afiliation (motivation); Parents.

\section{Resumo}

Este artigo tem o objetivo de apresentar um estudo de caso sobre filiação adotiva de dois irmãos maiores, interpretando como se deu a construção paterno-filial nesse processo. A coleta dos dados foi feita por meio de entrevistas de acompanhamento, totalizando 14 encontros com a família, durante um período de seis meses. Também foram utilizados dados obtidos através de um diário pessoal dos participantes. A análise do material baseou-se na perspectiva psicanalítica, identificando-se aspectos específicos do desenvolvimento da parentalidade e da filiação, bem como das etapas do estágio de convivência familiar. Observou-se que a possibilidade de escuta familiar das situações de maior ambivalência nas distintas etapas do processo auxiliou o processo de adoção e a filiação das crianças. Concluiu-se que a fundação familiar nos processos adotivos de crianças maiores não deve ser associada a maiores dificuldades de filiação, desde que se assegure um adequado atendimento das demandas parentais e filiais ao longo do processo.

Palavras-chave: Adoção (criança); Afiliação (motivação); Pais.

\footnotetext{
$\checkmark v \nabla v$
}

1 Universidade do Vale do Rio dos Sinos, Escola de Saúde, Programa de Pós-Graduação em Psicologia. Av. Unisinos, 950, 93022-000, São Leopoldo, RS, Brasil. Correspondência para/Correspondence to: S.P.C. BENETTI. E-mail: <spcbenetti@gmail.com>.

Article based on the master's thesis of the C.L. SILVA, untild "Processo de filiação: um estudo de adoção de dois irmãos maiores". Universidade do Vale do Rio dos Sinos, 2011. 
From a legal perspective, children or adolescents deprived of their biological parents and adopted by a family have all the rights and are subjected to all duties of this relationship supported by this new family. Hence, in the formation of this new family, the adopted child becomes son or daughter (Brasil, 2009). The adoption of an older child refers to situations in which children are older than two years old (Vargas, 1998). In this model of adoption the child is seen as a participant of the adoption process because the child's history of life and personal identity permeate the establishment of filiation (Solon, 2008).

Nonetheless, the law by itself does not ensure that an affective loving bond will be established between the child and adoptive family. This process is seen from a psychoanalytical perspective based on the establishment of filiation that includes both the parents' desire, and that of the child (Dolto \& Hamad, 1998), to form a new family. In this sense, Lévy-Soussan (2010) elaborating on the teachings of Guyotat (1995), considers that the biological bond missing in an adoptive filiation is compensated by the legal bond that ensures the rights of adoptive parents so that later, symbolic and affective ties are established. It is precisely the establishment of these ties that confers qualitatively more complex characteristics to the family formation.

In principle, empirical studies show that the transition to adoptive filiation tends to be immediate and abrupt while affective bonds are not yet established much less are parental roles firmly defined, which greatly differs from filiation established with biological parents (Levy-Shiff \& HarEven, 1991). Additionally, Weir (2003) considers that this accelerated transition seems to be especially more tense and unstable when the adopted child is older. Research shows that adoptive parents are afraid of adopting older children fearing the child's previous experiences, genetic hereditariness, or poor habits acquired in the orphanage (Costa \& RossettiFerreira, 2007; Vargas, 1998; Weber, 2001).

Studies suggest that there are specificities in the establishment of filiation concerning the adoption of older children (e.g. such as the uncertain 122 wait that differs from the period of a pregnancy, idealizations held by parents in regard to the child, especially among infertile couples, the "honeymoon" phase, which is more intense than in biological families, and the "bitter moon" phase (equivalent to "Lua de fel" in Portuguese, a pun on "Lua de Mel" meaning honeymoon), which, a priori, do not necessarily mean that problems will be faced in the future (Lévy-Soussan \& Marinopoulos, 2010a).

In France, according to Trindade-Salavert (2010), the follow-up of parents waiting for adoption is intended to facilitate the development of the adoptive project, which enables adoptive parents to elaborate on the desire of parenthood and identification with the child, favoring an "intrapsychical modeling" primarily grounded on the histories of each parent. It is the inner search of the unconscious, of projects linked to the desire to be a father or mother, which can be either reaffirmed or denied. Hence, this follow-up also allows for adoptive parents to re-consider the adoption and quit the process. Later, upon the arrival of the child, especially in adoptions involving more than two siblings, "diagnostic" sessions take place. According to the author, the main purpose of this follow-up is to facilitate identification between the adoptive parents and child or children and integrate experiences and the resumption of family history in transgenerational histories (Trindade-Salavert, 2010).

Based on these aspects, this paper focuses on a case study of the adoptive filiation of two older siblings considering identification and the understanding of family formation, more specifically on the stages concerning becoming a father, a mother, and son and daughter. Therefore, the purpose was not only to verify the legal, social and cultural aspects of the process, but also reflect upon its emotional aspects grounding the analysis on the psychoanalytical view of subjects' structuring on adoptive filiation.

\section{Method}

\section{Participants}

The research was conducted with the Silva Brasil family. The family members who participated 
in the study were both parents, Juca (father) and Luz (mother), and the adopted children, Rico (son) and Mila (daughter). All the names are fictitious to preserve the interviewees' identities.

\section{Instruments}

Data was collected through interviews held in 14 meetings over the course of six months. Also, the family registered their experience in a Personal Diary.

\section{Procedures}

The study was organized around a methodological longitudinal qualitative vertex using the case study of the Silva Brasil family. Four preparatory meetings were conducted with the children and one meeting was conducted with the prospective parents before they reached a final decision. After which, the children visited the couple's home. Upon final decision on adoption, the children left the institution and started living together with the parents and the family was monitored for six months.

Anamnesis and clinical interviews were conducted with both parents and siblings in the first follow-up visits. The interviews were considered an opportunity for reflection and free association concerning cohabitation, everyday routine, and issues concerning filiation. A personal diary was also provided to each family member where they should record their perceptions on the process according to the question: What is it like the process of becoming - father, mother, son and daughter in the adoption of older siblings? In the last meeting, the family returned the personal diaries and the follow-up ended.

All the interviews were transcribed verbatim as well as the reports obtained in the personal diaries. The participants' histories, the first interviews and follow-up interviews together with the personal diaries were used to build the case, while the focus was gathering the meanings assigned by the adoptive family such as fantasies, fears, denials, repetitions, ties, and identifications. In interpretative terms we used psychoanalytic understanding contextualized according to the context described in the case.

As the family was invited to participate in the study, the research topic was introduced. The family received clarification regarding the importance of their participation, the study's objectives, and issues concerning ethics and confidentiality. The couple signed free and informed consent forms in compliance with the Resolutions 196 from the Brazilian Council of Health and 016/ 2000 established by The Federal Council of Psychology. Approval was also provided by the Institutional Review Board at Universidade do Vale do Rio dos Sinos (Resolution no 10112010, CEP 101066, Project version: July 19, 2010).

\section{Results}

The children were sent to institutional care because Ruth, the biological mother, neglected and abandoned them. Ruth would let the children alone at home without clothes or food to make use of narcotics. At the time of preparation for adoption, the boy, Rico, was ten years old and his sister, Mila, was three and a half years old. In regard to Rico's health condition, he presented a diagnosis of chest deformity and congenital heart disease and was expecting surgery in the near future. Mila presented minor problems but needed surgery due to tonsillar hypertrophy.

The four interviews concerning the preparation for adoption were held at the children's institution and the purpose was for Rico and Mila, to imagine, fantasize and reflect upon the possibility of living with other people who would become their adoptive parents. Rico realized that he and Mila would be adopted. Even though Rico expressed an almost logical view in his understanding concerning the process, he was concerned with the possibility of not getting along with the parents and vice-versa. Mila, given her young age, asked all the time for the researcher's objects such as lipstick, make up, which indicated a strong need for identification. 
After the initial meetings, Juca and Luz visited the institution to meet the children. At the beginning, Rico and Mila, remained quiet, watching. Slowly, they started talking and describing their routines as if offering themselves to the couple. The father remained quiet, acting more like a companion. At the end, the couple invited the children to spent two days with them and Luz called them "my bonbons".

In the next interview, after the positive visitation during the weekend, Rico and Mila left the institution. Rico remained distant, observing the couple while their luggage was loaded into the car. Mila spontaneously interacted with $L u z$, clearly showing her desire for the adoption.

In the $7^{\text {th }}$ and $8^{\text {th }}$ meetings with the family at their home, Juca and Luz reported their personal histories. They were married for 23 years. Juca was 52 years old and was retired due to spine problems. Both were African-descendant. In the beginning of their marriage, $L u z$ helped raising a niece and later she helped raising Juca's nephew. Luz was 49 years old and was a public employee. For 17 years, however, she never wanted to have children because of the repeated and prolonged absences of her husband due to business travels. According to Luz, the desire to adopt children came from Juca, who had oligospermia. The couple had been entitled by the district to adopt children six years ago. Initially, they wanted to adopt an Africandescendant child up to one year old without mental disabilities. There was the possibility of adopting siblings, however, the preference was for twins up to one year old. After the course of preparation for adoption, however, the child profile changed and they agreed with the adoption of the siblings under study. clinical interviews were initiated. The family showed rapport, exchanging affections with each other. Rico and Mila disputed Luz's attention. Mila repeatedly asked for her bottle and also for Luz's backpack and lipsticks. Rico would advance with this body and try to get underneath the mother's blouse. Both Luz and Juca verbalized that the experience was 124 being tiresome but they considered everything was great and they were very happy. They also reported that, at different points in time, both Rico and Mila decided to call them mother and father. Luz said: "These are our children". The family was experiencing the "honeymoon" phase.

The $10^{\text {th }}$ clinical interview took place one month after when Luz declared that "things" were becoming very difficult. Additionally, Rico was fighting at school. The father verbalized that if Rico was not happy with them and wanted to leave, he would take him back to the institution, raising the possibility of returning the boy. Insecurity and instability settled in in the relationship between father and son, hindering Rico's establishment of filiation. At this point, they were experiencing the "bitter moon" phase. Despite the visible tension, we discussed that the children's behavior was a sign that they could finally express their aggressiveness, relying on the safe relationship they had with the adoptive parents.

In the $11^{\text {th }}$ interview many complaints regarding Rico persisted. According to $L u z$, it seemed that Rico only sought for trouble at school. At this point, surprisingly, Juca refuted saying the boy was communicative at school and many people liked him. By defending the boy, the father showed identification with his son, what was reflected on the boy's reports saying he liked his father's things, imitating his haircut and supporting the same soccer team while Luz and Mila supported another team. This identification with the father, enabled the emergence of oedipal issues.

In the same occasion, the father mentioned the daughter's difficulty in complying with rules, noting that she would mimic Rico all the time, tease him and dispute with the boy the parents' attention. There was a rupture in the family narratives, which no longer exclusively focused on Rico. At the end of the meeting, Juca and Luz expressed the importance of having follow-up after adoption due to the possibility of changing the way they dealt with the children and learn more about the process.

Some changes had take place in the couple's routine at the time of the $12^{\text {th }}$ interview. Mila had entered a full-day preschool. For this reason, Mila's adaptive process receded and she went back to 
using diapers and bottle. Rivalry between the children intensified and Rico's difficulties at school remained. During this meeting, we noted that up to the adoption, the children could not manifest fraternal rivalry, so common in child development, because they only had each other while living in the institution. Gradually, they allowed themselves to express issues inherent to the development process, which are considered here in the context of children who had a traumatic experience of abandonment.

In the last interview, Rico and Mila were acclimatized, they had friends on the street where they lived and at school, and played together and got along. Rivalry, however, persisted as well as discussions and fights over the parents' attention. The parents complained about they disobeying rules and limits, and also complained about the fights. Luz had resumed work and Mila stayed at school full day. At this point, however, the couple understood that the problems they were facing was a common routine faced by families when children enter school and the mother resumes work, among other aspects. This finding was very important for Juca and Luz because it enabled them to acquire a different understanding of family relationships. The couple concluded the meeting saying that despite the setbacks and difficulties handling and negotiating with the children, they were happy with the new family formation and believed they would progress even more with their affective relationships and establishment of bonds.

\section{Personal diary}

Luz's diary presented a very rich material and was based on the stages of the filiation process:

I'm fulfilled with my children. I want them forever, to love them and be happy, the four of us..." Finally, during the last month Luz wrote: "Our family has a long way to go, but we are increasingly united by love despite the different personalities of each... I'm happy, I love my children, and God willing, we will make them the happiest children in the world.
And the entire family signed the diary.

Juca's personal diary was empty. He claimed he did not know what to write or how to express himself. Juca, however, helped Mila with a drawing that represented them both together. The pages of the girl's diary were all filled showing she improved from scribbling, which evolved from curved lines into doll-like figures. Rico also considerably used the diary, labeling it "Rico's dairy". In regard to the family, Rico wrote: "[...] Mother and father are very nice. Father is angry, but it's his way. Mother takes Mila to school and father takes me to school. The school is small, but not everything is big".

\section{Discussion}

The main goal of this study was to monitor the process of family formation in the case of adoption of two older siblings with special focus on the understanding of filiation on the part of the adopting couple, Juca and Luz, and their children Rico and Mila. According to Cunha (2007), there two key elements organizing the family context: the family's discourse and desire. In the case under study, we observed the manifestation of unconscious parameters inherent to family structuring concerning the desire of filiation both from the perspective of the couple and the children.

The profile of the child they initially wanted to adopt was different from that of the children they actually adopted. Nonetheless, the culture of adopting older children was already internalized by Juca and Luz because they had helped raising children in the family, indicating there were unconscious inclinations, which, somehow supported the option for Rico and Mila (Trindade-Salavert, 2010). Acceptance of a child with characteristics different from what they had first envisioned took place due to meetings intended to prepare prospective couples. In this same sense, Gondim et al. (2008) also identified, among adoptive parent support groups, a process in which candidate couples adapt the profile of children they want to adopt. This preparation, however, is not restricted to encouraging prospective parents to accept the 
child's characteristics but it is mainly intended to introduce the filiation process that supports and sustain affections linked to the transformation between the idealized and the adopted child.

When Rico and Mila left the institution to go to the adoptive parents' home was a moment of celebration, represented by the expansive attitude of Luz. Insecurity and fear regarding the filiation process, however, were also expressed by the watchful and quiet attitude of Juca. Likewise, the children showed fear expressed by Rico's concern in being accepted by the new family.

The couple's history showed that the desire in adopting a child came from Juca due his infertility. Perhaps, Juca put himself in the background due his own ambivalences. Luz, was rather open to change and willing to take the children from the institution. There was, however, an idealized view of the process that would not ensure a successful adoption. Rico and Mila in turn, due to the trauma they had experienced before, required from the couple intensive psychological investment so that an affective relationship and parental ties would be established.

In general, the adoption of older children is permeated by specificities in the construction of filiation that results from the waiting for the child, the idealization of the process, and the regressive response of the child in the beginning of life living together with the family (Lévy-Soussan \& Marinopoulos, 2010a; 2010b). Ozoux-Teffaine (1987) note that older children expect they will re-live the primitive relationships experienced with the mother in the new family relationship. Hence, regression emerges immediately after the adoption when the child manifests a desire to reborn in different ways as a form to restore the narcissistic order and revert psychological damage.

These situations were observed in the first meetings with the family, mainly expressed by the need of both, Rico and Mila, to establish body contact with the mother. The kisses, hugs, and attempts of body reintroduction represented by an effort to get underneath Luz's clothes were an attempt to recreate their origins. During the same 126 period, Mila allowed herself to establish filiation by enrolling herself in the family genealogy. Hence, she constantly invested in the parents, demanding attention and at the same time reciprocating affections. Meanwhile, Rico remaining more distant from the family, manifesting a more imperious and authoritative behavior, not contributing much to his filiation process. This behavior, however, resulted from his experiences with abandonment, fear it would happen again, and fear of establishing new affective bonds. As a whole, these behaviors demanded psychological energy and investment on the part of Luz and Juca. Nevertheless, the couple was very satisfied and coping with changes.

After the "honeymoon" phase, the "bitter moon" phase settled in, a time permeated of instability that led to persecutory fantasies, jealousy, fear of reliving the narcissistic wounds and aggressiveness among the subjects (Lévy-Soussan \& Marinopoulos, 2010a; 2010b). These aspects were observed in the $10^{\text {th }}$ meeting with the family when the dispute between the children over the mother was very intense, increasing tension in the reconstruction. Instability was perceive on the part of Rico and Mila and also on the part of the parents, with feelings of ambivalence, rejection, approximation, aggressiveness and affectivity. At this point, the couple feared not being able to become a family and had to prepare the mourning for their relationship as a couple to rebuild the family. Rico and Mila needed to overcome their fear of rejection and the possibility of being returned to the institution because the phase to test the parents' love had been initiated.

Studies addressing the adoption of older children show that children usually test the adoptive parents' acceptance. Hence, the parents need to be prepared to deal with this possibility and not take such a situation as a personal aggression, rejection or provocation but part of the adaptation process of living together and establishing a relationship, which involve becoming an adoptive father, mother and adopted child (Brodzinsky, Smith, \& Brodzinsky, 1998; Solon, 2008; Vargas, 1998). This paper shows that the mother expressed both affection and aggressiveness in her process of identification with the children. The same feelings were expressed by Juca, who even proposed 
sending Rico back to the institution. The followup, however, enabled the couple expressing their aggressive fantasies regarding the children and showed the importance of a psychoanalytical listening that take into account the individual's ambivalence in the face of his/her desire and provide guidance.

In summary, the qualification of all the technicians involved in adoption, who should be prepared to intermediate the process, is essential for a successful adoptive process. Furthermore, the professionals should have in mind that listening to the family at times of greater difficulty cannot be biased or devalue the family's experiences, rather it should be an opportunity to encourage transformation.

\section{References}

Brasil. (2009). Presidência da República. Lei n 12.010, de 3 de agosto de 2009. Estatuto da criança e do adolescente.

Brodzinsky, E. D. M., Smith, D. W., \& Brodzinsky, A. B. (1998). Children's adjustment to adoption. Thousand Oaks, C.A: Sage.

Costa, N. R. A., \& Rossetti-Ferreira, M. C. (2007). Tornar-se pai e mãe em um processo de adoção tardia. Psicologia: Reflexão e Crítica, 20(3), 425-434.

Cunha, D. F. (2007). Construção da subjetividade... É diferente no filho adotivo? (Tese de doutorado não-publicada). Universidade Federal do Rio de Janeiro.

Dolto, F., \& Hamad, N. (1998). Destinos de crianças: adoção, famílias de acolhimento, trabalho social. São Paulo: Martins Fontes.

Gondim, A. K., Crispim, C.S., Fernandes, J. C. R., Brito, T.M.C., Oliveira, U.B., \& Nakano, T. C. (2008).
Motivação dos pais para a prática da adoção. Boletim de Psicologia, 58(129), 161-170.

Guyotat, J. (1995). Filiation et puerpéralité, logique du lien: entre psychanalyse et biomedicine. Paris: PUF.

Levy-Shiff, I. G., \& Har-Even, D. (1991). Transitions to parenthood in adoptive families. Developmental Psychology, 27(1), 131-140.

Lévy-Soussan, P. (2010). Trabalho de filiação e adoção. In I. Trindade-Salavert (pp.45-80). Os novos desafios da adoção: interações psíquicas, familiares e sociais. Rio de Janeiro: Companhia de Freud.

Lévy-Soussan, P., \& Marinopoulos, S. (2010a). Mini-curso de preparação das equipes especializadas em adoção. In I Congresso Franco-Brasileiro de Psicanálise, Filiação e Sociedade. Recife: Universidade Católica de Pernambuco.

Lévy-Soussan, P., \& Marinopoulos, S. (2010b). Abandono e adoção: os desafios psíquicos da filiação numa perspectiva histórica e clínica. In I. Trindade-Salavert. Os novos desafios da adoção: interações psíquicas, familiares e sociais (pp.81-108). Rio de Janeiro: Companhia de Freud.

Ozoux-Teffaine, O. (1987). Adoption tardive: d'une naissance à l'autre. Paris: Stock-Laurence Pernoud.

Solon, L. A. G. (2008). Conversando com a criança sobre adoção. São Paulo: Casa do Psicólogo.

Trindade-Salavert, I. (2010). Os novos desafios da adoção: interações psíquicas, familiares e sociais. Rio de Janeiro: Companhia de Freud.

Vargas, M. M. (1998). Adoção tardia: da família sonhada à família possível. São Paulo: Casa do Psicólogo.

Weber, L. N. D. (2001). Pais e filhos por adoção no Brasil: características, expectativas e sentimentos. Curitiba: Juruá.

Weir, K. (2003). Adoptive family "leap-frogging" patterns. Adoption Quarterly, 7(1), 27-41.

Received: December 18, 2012

Final version: July 22, 2013

Approved: August 20, 2013 
